\title{
ALTERNATIVE SOURCES OF FINANCING ENTREPRENEURIAL UNDERTAKINGS IN AGRICULTURE
}

\author{
Vladimir Njegomir ${ }^{1}$, Rajko Tepavac ${ }^{2}$, Nenad Ivaniševićc ${ }^{3}$
}

\begin{abstract}
Summary
Insufficiency of internal financial resources and limited access to external sources of capital, as one of the key problems, local agricultural producers - entrepreneurs usualy describe with high cost of capital, complicated procedures, lack of transparency in regard to the settlement of credit requests and problems with security of loans. The aim of this study is to analyze the possibilities of facilitating access to increased volume of capital for domestic entrepreneurs in agriculture by using funding sources that are applied in developed economies for financing entrepreneurs. In order to achieve the stated aim, the subject of investigation in this paper is the analysis of alternative sources of financing, which use or increased adoption in Serbia would provide greater availability of capital for agricultural producers and others across the chain of agrobusiness complex and thus the promotion of entrepreneurial activity, and consequently, greater competitiveness and greater income of domestic agricultural producers and others across the chain of agrbusiness indirectly leading to increased economic growth and improvement of the welfare.
\end{abstract}

Key words: entrepreneurship, agriculture, microcredits, business angels, risk capitalists and crowdfunding.

JEL: Q01, Q14, L26.

\section{Introduction}

All activities in agricultural production are permeated by entrepreneurship. Without innate entrepreneurship local agricultural producers could not survive. Entrepreneurship

1 Vladimir Njegomir Ph.D., Associate Professor, Union University, Faculty of Law and Business Studies, Dr Lazar Vrkatić, Bulevar oslobođenja no. 76, 21000 Novi Sad, Phone: +381641393 005, E-mail: vnjegomir@eunet.rs

2 Rajko Tepavac Ph.D., Associate Professor, Institute for economics and finance, Bulevar Mihajla Pupina no. 10 B/I, 11000 Belgrade, Phone: +381 63600 217, E-mail: tepavac57@gmail.com

3 Nenad Ivanišević, Ph.D., Assistant Professor, Ministry of Labour, Employment, Veteran and Social Affairs of the Government of the Republic of Serbia, Belgrade, Serbia, E-mail: nenad.ivanisevic@gmail.com

EP 2017 (64) 1 (295-306) 
is especially important in the chain of agribusiness complex, which includes all subjects from primary agricultural production to the production of distribution of food products. Agribusiness consists: small family farms, farms, large agricultural corporations, credit institutions, suppliers of inputs, manufacturing companies, Transport network, wholesale, marketing, restaurants and retail food. Farm is the main business entity in the system of agribusiness. Farm is agricultural holding specialized in market production. Those farms are advanced farms that use modern manufacturing techniques and technology.

Entrepreneurship provides answers to questions of how, by who and with what consequences are detected, created and exploited opportunities for introducing new products and services (Venkataraman, 1997). Entrepreneurship is an individual creative capacity, independent or within the organization, for identification and realization of opportunities in order to produce new value or economic success (EC 2003). From these two definitions of entrepreneurship, it is clear that entrepreneurship is directly related to agricultural production, although individual farmer is not an entrepreneur in the meaning of Article 83 of the Companies Law (2015). However, according to the interpretation of the Ministry of Finance of the Republic of Serbia (2016), an individual who earns income by conducting agricultural and forestry activities, and income from the sale of agricultural and forest products acquires entrepreneur status by the force of the law or by their own commitment. Entrepreneurship is inherent to agribusiness complex.

The key problem of entrepreneurship in agricultural production and also in agribusiness complex is the lack of financial resources. In Serbia, we are faced with a large number of small individual entrepreneurs in agriculture and a few big ones. Access to finance as well as the range of loan products to the agricultural sector in Serbia is very poor (Veselinović, Drobnjaković, 2014). The situation can be improved by increasing the availability of capital from alternative sources of financing.

Alternative sources of financing entrepreneurial ventures represent sources of financial assets that are not common in Serbia and have a relatively important role in the world, especially in the area of financing beginners in entrepreneurship or farmers and other entrepreneurs who have lower credit ability in developing countries. The most important alternative funding sources are micro-credits, business angels, venture capitalists and crowdfunding. In developed countries, especially in the US, hedge funds give the financial support to the promising entrepreneurial ventures primarily through investments in securities (Njegomir, Cirić, 2013). In Serbia, according to the study (Erić et al., 2012), recently the participation of business angels and venture capitalist is present in a very small scale compared to other sources of funds and only in certain industries, especially information and communication industry. According to research (Erić et al. 2012) entrepreneurs in Serbia in all industries from non-bank sources of financing mainly use government assistance (70\%), then micro-credits from nonbank entities $(11,7 \%)$, help from friends and relatives $(10 \%)$, business angels $(5 \%)$ and finally venture capitalists (3.3\%). 
The goal of this paper is to analyze the possibilities to facilitate access to increased volume of capital of domestic entrepreneurs in agriculture by applying the financing sources that are applied in developing countries. In order to achieve goal, the subject of this paper is the analysis of alternative financing sources whose application or greater application in Serbia would enable a greater availability of capital and the improvement of entrepreneurial activities in agriculture and its competitiveness and profitability.

\section{Methodology and data sources}

Our research is focused on the analysis of the alternative sources of financing entrepreneurial undertakings in agriculture. As our kind reviewrs stated, there are up to 900,000 hectares that are uncultivated on the one hand and the lack of available capital on other. By using statistical analysis we explore the key problem of the lack of financial resources for financing agricultural ventures in alternative ways.

We compare four alternative sources of financing that can supplement traditional financing in various cases, by comparing foreign theorethical knowledge and empirical evidence in Serbia. We analyse the application of business angels, private equity investors, crowdfunding and microcredits as alternative sources of financing. The basic intent is to change the traditional view of available sources of financing and to foster more research in the application of alternative instruments that have been proved in developed or developing countries. The analysis of each alternative financing mechanisms, review of current achievements in other countries and comparative analysis of alternative mechanisms is done in order to determine what is done and what is neded to be done to improve the availability of financial resources of agricultural ventures.

Data are gathered from verious trustfull sources. We use sources of various leading scientists in the field of agricultural economics and entrepreneurship, including Nobel prize winners among them. We base our conclusions on data from United Nations, Organisation for Economic Co-operation and Development, FAO and other sources.

\section{Business angels}

If the business idea does not require considerable financial resources, as is the case with local agricultural producers - entrepreneurs, and if it is not a type of business that will ensure the achievement of high profits, instead of venture capitalists, financial assets can provide business angels. Business angels are investors, wealthy individuals who place their capital in start-ups as well as in new established small entrepreneurs who are not able to provide funds for starting business in any other way.

Business angels are wealthy individuals who individually or trough associations invest their capital, knowledge and business contacts in development of business ideas with potential for rapid growth. In this case, the investments in producers of food products are more interesting for business angels. In the world, special place takes investments in organic production that has great potential for rapid realization of significant profit. 
Although, there are not exact data, it is considered that business angels in US represent informal market of venture capital and that they also have the largest reserves of free capital for investments (Hisrich, Peters, Shepherd, 2008). One of the most famous business angels is Bill Gates, who placed the funds in a number of biotech start-up companies. It is estimated that each year over 100,000 independent investors finance between 30,000 and 50,000 entrepreneurs in total dollar amounts that range between 7 and 10 billion dollars (Hisrich, Peters, Shepherd, 2008).

Basic characteristics of business angels in the US are shown in table 1. Beside capital, business angels assign to entrepreneurs their own experience, skills and contacts in order to contribute in prosperity of entrepreneurs. Also, additional motives for investment include active participation in the entrepreneurial process, enjoying the fact that they are part of a successful investment and a sense of contributing to the development of society as a well (SBAN, 2016). Unlike in developed countries, in Serbia this form of financing of entrepreneurs is not significantly represented although there is Serbian Business Angels Network (SBAN, 2016).

Table 1. Characteristics of business angels

\begin{tabular}{|l|}
\hline Demographic patterns and relations \\
\hline Well educated, many have college education. \\
\hline They are ready to finance entrepreneurs from any part of the world. \\
\hline Most of the companies financed by them are at a distance of one day trip. \\
\hline Most of them expect to play an active role in the venture that are funded. \\
\hline A large number belong the Angel Business Club. \\
\hline Characteristics of investments \\
\hline The range of investments: $\$ 10,000$ - $\$ 50,000$ \\
\hline Average investment: $\$ 175,000$ \\
\hline One to two investments per year. \\
\hline Companies that have advantages \\
\hline The companies in its initial stages or under the age of 5 years are mainly funded. \\
\hline The most interesting areas for investments: \\
\hline Production: industrial / commercial products \\
\hline Production: consumer products \\
\hline Energy / natural resources \\
\hline Services \\
\hline Software \\
\hline Expectations regarding the risk / return \\
\hline Average five-year capital income of 10 times for the company in the beginning \\
\hline Average five-year capital income 6 times for companies younger than 1 year \\
\hline Average five-year capital income 5 times for businesses aged $1-5$ years \\
\hline Average five-year capital income for the company 3 times older than 5 years \\
\hline
\end{tabular}




\begin{tabular}{|l|}
\hline The reasons for rejection of offers \\
\hline Inadequate extent of risk in relation to the income. \\
\hline Inadequate management team. \\
\hline Lack of interest in the proposed area of operation. \\
\hline Failure to reach a deal on the price. \\
\hline The owners do not show adequate commitment. \\
\hline Insufficient knowledge of the business area. \\
\hline
\end{tabular}

Source: Hisrich, Peters, Shepherd, 2008.

Business angels rarely have a direct contact with the company before they decide to invest, but at the same time often have experience in the industry in which they are investing. Financial benefits are the motive of most business angels. However, there are additional motives for investments, such as active participation in the entrepreneurial process, enjoying the fact that they are part of a successful investment and a sense of contributing to the development of society as well.

Capital of business angels is suitable source of funding for entrepreneurs in many reasons, such as (Erić et al., 2012):

- No refund of money, unlike a loan or leasing,

- beside capital, they can offer knowledge and experience in providing support for entrepreneurs,

- if the entrepreneur is developing and growing, they can also be a source of further financial investments and a stable financial operations and

- They improve the system of business operations and management of entrepreneurs by distributing their assets in them.

\section{Venture capitalists}

Venture capitalists are the source of financing entrepreneurs in their early stages of development of in later stages, when they need resources for further development. Thanks to the fact that they provide financial resources for the risky ventures and that their resources are bound to venture they are called venture capitalist.

Venture capitalist estimates whether a venture with a good business idea has a chance, if it has an innovative and entrepreneurial potential and business prospects to develop, grow and become competitive in order to enable the achievement of high rates of return on invested capital. Venture capitalists typically invest in those projects that may provide them 6 to 10 times more revenue compared to the investment during the fiveyear period, or in projects that can provide a return on investment of $45 \%$ (Mariotti, Glackin, 2016). Such profits cannot be produced in ordinary farms in Serbia, but some with rounded up organic production may be with high potential for growth. That also holds for agricultural producers of in demand organic food, which is higher priced than ordinary or not organic. 
Venture capitalists will not invest in some entrepreneurial venture unless the condition of certain amount of annual turnover is fulfilled. It is common in the United States that the minimal turnover within five years is about $\$ 25$ million and that ideal turnover is higher than 50 million dollars and that at the same time has an annual growth rate of 30 to 50 percent, with a predicted profit of 20 percent before tax (Mariotti, Glackin , 2016). If the assessment is positive, the funds are invested in the entities which provide share in capital or shares, and along with that ownership and management rights and income on that basis.

Investors in venture capital on the basis of their investment bear all risks of business success or failure of the venture in which they invest. We emphasize that the risk of such investments is extremely high and investors expect high profits from these investments. Entrepreneurial capitalists get their earnings from selling shares to other investors or they wait entrepreneur to start initial public offering, when they get their earnings by selling shares. Private equity funds are similar to venture capitalists.

For venture capitalists and private equity funds is characteristic that they do not invest their own capital but they collect financial funds from a number of institutional and individual investors. Private investment funds are characterized by relatively high rates of return expected from entities and generally they range from 20 percent or more. They are mostly minority shareholders in capital. Mostly they are involved in strategic management, but they also can be included in operational management.

Table 2 shows the basic differences between venture capital or risk investors and business angels.

Table 2. Key differences between business angels and venture capital

\begin{tabular}{|c|c|}
\hline Business angel & Venture capitalist \\
\hline - Individual investor & - Company or fund as an investor \\
\hline $\begin{array}{l}\text { Invests in entrepreneurs in the } \\
\text { beginning or in newly established } \\
\text { business entities }\end{array}$ & $\begin{array}{l}\text { Invests in business entities in early stages, } \\
\text { especially with the rapid development }\end{array}$ \\
\hline $\begin{array}{l}\text { - They invest mostly in the range of 10- } \\
100 \text { thousand pounds, and as a group } \\
\text { may invest up to } 1 \text { million }\end{array}$ & $\begin{array}{l}\text { - They invest generally in amounts higher } \\
\text { than million pounds. }\end{array}$ \\
\hline $\begin{array}{l}\text { - They have the experience and } \\
\text { contacts }\end{array}$ & - They have contacts \\
\hline $\begin{array}{l}\text { - They may require inclusion in } \\
\text { business }\end{array}$ & $\begin{array}{l}\text { - They require participation in the Executive } \\
\text { Board }\end{array}$ \\
\hline
\end{tabular}

Source: The Business Angel (2016).

Generally speaking, the entrepreneurial ventures in agriculture, agribusiness and other industries in the early stages, the most likely source of financing will be business angels. Venture capitalist may occur in the later stages of business when the entrepreneur is confirmed and when the initial revenues are generated. 


\section{Crowdfunding}

Crowdfunding is essentialy financing of agrocultural producers and others across the agrobusiness chain by collecting financial resources from large number of people. The concept of "crowdfunding" is related to the one of "crowdsourcing", which refers to the outsourcing to the "crowd" of specific tasks, such as the development, evaluation or sale of a product, by way of an open call over the internet (Howe, 2008). Crowdfunding provides cheaper and faster financing as entrepreneurs can go directly to investors, suppliers and customers for money at much lower interest rates than those of banks. Crowdsources may in fact have intrinsic motivations, such as the pleasure of undertaking the task or participating to a community, as well as extrinsic motivations, related to monetary rewards, career benefits, learning or dissatisfaction with the current products (Kleeman et al. 2008).

Crowdfunding as a form for financing entrepreneurs originated in Australia. First to implement crowdfunding was Australian Small Scale Offerings Board (2017) that from 2006 helped more than 200 businesses to raise more than 128 millions of US dollars. However, this form of financing was faster implemented by some western European countries, notably the UK as well as the USA. Numerious web sites for crowdfunding has been created as internet facilitated the growth of crowdfunding.

Crowdfunding can take the form of (OECD, 2015):

1. Donations, whereby contributors donate funds, mostly for charities and nonprofit organisations, although for-profit organisations can also receive donations through this channel;

2. Reward or Sponsorship, whereby contributors receive a pre-defined reward, such as a small token of appreciation or some type of service, like a public acknowledgment for their contribution and marketing;

3. Pre-selling or pre-ordering, whereby investors provide funding to help produce some product or service and in return receive an early version of the product, or the product at a reduced price;

4. Lending, whereby investors receive the interest and the principal at the end of the lending period. There exist also crowd-lending forms based on the revenuesharing principle, that is, where creditors are not paid interests at the end of the defined lending period, but rather an amount which includes an agreed share of the earnings, in case of good performance of the debtor.

5. Equity, whereby a privately-held company offers securities to the general public, through the medium of an online platform. Investors receive a share in the business and may acquire voting rights.

In agriculture and agribusiness, crowdfunding is usually used in developing countries as a form of donations from people of the same local community. Crowdfunding is a useful tool which can strengthen the relation between agri-food producers and consumers (Yoo, 
Choe 2014). Rutten and Fanou (2015) the application of crowdfunding in agriculture see as a form of innovative and inclusive finance for the youth in agriculture.

Some form of crowdfunding is known in Serbia. Humanitarian fundraising is nothing else than donations. So, we are of the opinion that this form of entrepreneurship financing could be easily implemented in Serbia. Donations, sponsorships and pre-selling are already present in Serbia and for their development with the aim of entrepreneurship financing there would be any need for government regulation, as it would be for crowdlending and offering securities to the general public, especially over the internet.

In agriculture entrepreneurship in Serbia crowdfunding could be applied using rural networks, cooperatives, agricultural fairs, internet web sites dedicated to agriculture and rural development. In either way, crowdfunding of agricultural producers will help them to bridge timing differences in the production cycle at least. Further benefit would be buying more land and linkage of husbandry and livestock breeding with production of various food products as is seen in developed economies. Additionally, rural areas could develop local food producers, like local diary or production of various flour or corn products. In addition to the development of agriculture and rural areas such crowdfunding will benefit all people interested for such development in local communities, at national level as well as people around the world. For small, individual's investors it would be the opportunity to put their own money where "their opinions, beliefs, dreams and aspirations are" (Roocke, 2015).

\section{Microcredits}

Significant role in lending to farmers in some countries have a micro-credits. This type of loan is provided by microfinance institutions. Microfinance as a modality of providing financial services first developed in the field of loan providing or the so-called microcredits, initially provided by non-profit organization Accion International in 1973 (Njegomir, 2011). In the eighties of the twentieth century microfinance become an important component of development and poverty reduction worldwide. The success of microfinance institutions in the provision of small loans started a revolution in financial services sector worldwide. Support of media has contributed to the increased interest of commercial institutions in this sector.

During the nineties, the models of microfinance become more financially sustainable, the regulatory environment in a number of countries became favorable for microfinance institutions, and the development of new technologies and delivery channels of financial services made it possible to significantly reduce the costs which enable profitability of small individual transactions. Those changes have created conditions and influenced the development of institutions in this sector in more than 100 countries. For example, about 3000 microcredit institutions were registered in 1998 in developing countries (UN 1998). The development of microfinance role continued during the first decade of the new millennium. Thanks to the rapid development of micro-credits and their positive role in social, economic and political processes (Fernando, 2006), the year 
2005 was declared for the world-year of micro-credits by the General Assembly of the United Nations.

Based on the field research on microfinance in the rural farming communities in Remo Division of Ogun State, Nigeria, Nosiru (2010) found that micro-credits could have prospect in improving the productivity of farmers and contributing to uplifting the livelihoods of disadvantaged rural farming communities. In Serbia appeared microcredit funds that provide micro-credits to domestic farmers, usually in amounts ranging from 100.000 to 500.000 dinars. However, approval is done through commercial banks and that is why the use of those loans is more expensive than in other countries. Amendment of legislation that will allow offer of microcredit as a loan by the model of Mohammed Yunnus will allow easier and cheaper use of microcredit.

Engaging in microfinance sector proved to be profitable, which is evidenced by numerous examples, among them the BancoSol, a bank that was founded in Bolivia in the nineties and that was proclaimed for Bolivian bank of the year several years in a row on the basis of key financial indicators such as the rate of return on assets and capital and the quality of portfolio. One of the successful examples is the Grameen Bank, which was formed as a result of the experimental project in 1976 and established as a bank in 1983. The bank grants small loans for agricultural development and business mainly to women and the fact that the Bank and its founder Mohammed Yunnus won the Nobel Peace Prize in 2006 shows the significance of this bank. In the area of microfinance are present even the largest banks in the world such as Citigroup, Deutsche Bank, ING, etc.

\section{Conclusion}

In this paper, we have shown the key forms of financing starting entrepreneurial ventures, as well as existing in world in agricultural production and agricomplex. These sources, business angels, venture capitalists, micro-credits and crowdfundings, represent the opportunities for funding that are available to foreign entrepreneurs. Some of these alternative sources of funding are not present only in the developed countries. Microcredits are also present in developing countries, in poor rural areas.

Having in mind the significant potential of agriculture and agricomplex in Serbia, as well as the fact of extremely high share of agriculture in gross domestic product, enabling the presence of alternative sources of funding to traditional banking and state aid would allow accelerated development of agriculture and also food industry. Therefore, alternative sources of funding are crucial especially in sectors in which the current funding mechanisms in Serbia does not provide sufficient funds or those funds are prohibitively expensive.

Social commitment in Serbia is stimulating startup entrepreneurial ventures in all sectors. Considering that agriculture and agribusiness sector have great possibilities, the development of alternative forms of financing is necessary for the improvement of its competitiveness which will ensure greater profitability, ability of self-employment the development of rural areas and at the end it will effect as a stimulator of economic 
growth. The best way to solve problem of underemployment, especially among youth, and also of other social problems is the stimulation of entrepreneurship, especially in agriculture. The full capacity of entrepreneurship development in Serbia can be expected with the prior strengthening of alternative financing sources.

\section{References}

1. Australian Small Scale Offerings Board(2017): Internet platform for crowdfunding. Available at: https://assob.com.au/Default.asp (accessed 05.12.2017).

2. EC (2003): Green Paper: Entrepreneurship in Europe. Commission of the European Communities, 27 final, Brussels.

3. Erić, D.D. et al. (2012): Finansiranje malih i srednjih preduzeća u Srbiji. Privredna komora Srbije, Beograd.

4. Fernando, J.L. (2006): Microcredit and empowerment of women: blurring the boundary between development and capitalism. In J.L. Fernando (ed.): Microfinance: Perils and prospects, Abingdon, Oxfordshire, UK.

5. Hisrich, R.D., Peters, M.P. and Shepherd, D.A. (2008): Entrepreneurship. McGraw-Hill Companies, New York.

6. Howe, J. (2008): Crowdsourcing: Why the Power of the Crowd Is Driving the Future of Business. Crown Publishing Group, New York.

7. Kleeman F., Voss G.G. and Rieder K. (2008): Un(der)paid innovators: the commercial utilization of consumer work through crowdsourcing. Science, Technology \& Innovation Studies, Vol. 4, No. 1, pp. 5-26.

8. Mariotti, S. and Glackin, C. (2016): Entrepreneurship: Starting and Operating a Small Business. Pearson, Harlow, UK.

9. Ministarstvo finansija Republike Sribije (2016): Available at: http://www.mfin. gov.rs/UserFiles/File/misljenja/2013/Objasnjenje \%20vodjenje \%20poslovnih $\% 20$ knjiga(1).pdf (accessed 08.10.2016.).

10. Njegomir, V. (2011): Mikroosiguranje. Industrija, Vol. 39, No. 3, pp. 295-314.

11. Njegomir,V. and Ćirić, J. (2013): The importance of hedge funds: The point of view of insurance companies and other institutional investors. Strategic Management, Vol.18, No.1, 2013, pp. 37-46.

12. Nosiru, M.O. (2010): Microcredits and Agricultural Productivity in Ogun State, Nigeria. World Journal of Agricultural Sciences, Vol. 6, No. 3, pp. 290-296.

13. OECD (2015): New Approaches to SME and Entrepreneurship Financing: Broadening the Range of Instruments. Organisation for Economic Cooperation and Development, Paris, France.

14. Roocke, N. (2015): Crowdfunding - an option for projects in agriculture. Australian Canegrower. Available at: http://search.informit.com.au/ documentSummary; $\mathrm{dn}=666039688040090 ;$ res=IELAPA (accessed 20.12.2016). 
15. Rutten, L. and Fanou, S.L. (2015): Innovative and Inclusive Finance for Youth in Agriculture. In: A.K. Koira et al. (eds) Africa Agriculture Status Report: Youth in Agriculture in Sub-Saharan Africa, Alliance for a Green Revolution in Africa (AGRA), Nairobi, Kenya.

16. SBAN (2016): Serbian Businss Angels Network. Available at: http://sban.eu/ portal/index.php/site/index (accessed 29.11.2016.).

17. The Business Angel (2016): Difference between Angel Investors \& Venture Capital. Available at: http://www.thebusinessangel.org/difference-businessangelventurecapital.html (accessed 27.11.2016.).

18. UN (1998): Bulletin on Eradication of Poverty. United Nations, New York, November 1998. Available at: http://www.un.org/esa/socdev/poverty/documents/ boep 051998 EN.pdf (accessed 03.12.2016.)

19. Venkataraman, S. (1997): The distinctive domain of entrepreneurship research: An editor's perspective. In J. Katz and R. Brockhaus (eds.), Advances in Entrepreneurship, Firm Emergence, and Growth, JAI Press, Greenwich, pp. 119138.

20. Veselinović, B. and Drobnjaković, M. (2014): Qualitative and Quantitative Analysis of Micro and Macro Aspects of Agricultural Finance. Economics of Agriculture, Vol. 61, No. 3, pp. 771-787.

21. Yoo, Y.G. and Choe, Y.C. (2014): Current Status of Korean Crowdfunding Industry and its Applicability to Agrifood Sector. Advanced Science and Technology Letters, Vol. 49, pp. 213-221.

22. Zakon o privrednim društvima, „Sl. glasnik RS”, br. 36/2011, 99/2011, 83/2014 dr. zakon i 5/2015. 


\title{
ALTERNATIVNI IZVORI FINANSIRANjA PREDUZETNIČKIH PODUHVATA U POLJOPRIVREDI
}

\author{
Vladimir Njegomir ${ }^{4}$, Rajko Tepavac ${ }^{5}$, Nenad Ivanišević ${ }^{6}$
}

\begin{abstract}
Rezime
Nedovoljnost internih izvora finansijskih sredstava i ograničenost pristupa eksternim izvorima kapitala, kao jedan od ključnih problema, domaći poljoprivredni proizvođači preduzetnici uobičajeno opisuju visokom cenom kapitala, komplikovanim procedurama, odsustvom transparentnosti u pogledu rešavanja kreditnih zahteva i problema sa obezbeđenjem kredita. Cilj istraživanja ovog rada jeste analiza mogućnosti za olakšavanje pristupa povećanom obimu kapitala domaćih preduzetnika u poljoprivredi primenom izvora finansiranja koja se primenjuju u razvijenim zemljama za finansiranje preduzetništva. U nameri ostvarenja postavljenog cilja predmet istraživanja u radu čini analiza alternativnih izvora finansiranja čija bi primena ili veća primena u Srbiji omogućila veću raspoloživost kapitala poljoprivrednicima i svima u lancu agrobiznis kompleksa a time i unapređenje preduzetničkih aktivnosti, odnosno posledično veću konkurentnost i prihode domaćih poljoprivrednih proizvođača i svih širom agrobiznis kompleksa a indirektno ubrzaniji privredni rast i povećanje blagostanja stanovništva..
\end{abstract}

Ključne reči: preduzetništvo, poljoprivreda, mikrokrediti, poslovni anđeli, rizični kapitalisti, pojedinačne investicije.

4 Dr Vladimir Njegomir, vanredni profesor, Univerzitet Union, Fakultet za pravne i poslovne studije dr Lazar Vrkatić, Bulevar oslobođenja 76, 21000 Novi Sad, Telefon: +381 64139 3005, E-mail: vnjegomir@eunet.rs

5 Dr Rajko Tepavac, vanredni profesor, Institut za ekonomiku i finansije, Bulevar Mihajla Pupina 10 B/I, 11000 Beograd, telefon: 063/600217, e-mail: tepavac57@gmail.com

6 Dr Nenad Ivanišević, docent, Ministrarstvo za rad, zapošljavanje, boračka i socijalna pitanja Vlade Republike Srbije, e-mail adresa: nenad.ivanisevic@gmail.com 
ECONOMICS OF

AGRICULTURE

\section{CONTENT}

1. Željko Anđelković, Aleksandra Dragin, Sanja Božić, Kristina Košić

EMOTIONAL EXHAUSTION AND JOB SATISFACTION OF TOUR GUIDES IN RURAL AREAS . . . . . . . . . . . . . . 11

2. Sanja Đukić, Danica Glavaš-Trbić, Nikola Banjac

MANAGEMENT PROBLEMS OF RURAL DEVELOPMENT IN FRUŠKA GORA . . . . . . . . . . . . . . . . . . . . 27

3. Ivana Ilić, Bojan Krstić, Sonja Jovanović

ENVIRONMENTAL PERFORMANCES OF AGRICULTURE IN THE EUROPEAN UNION COUNTRIES . . . . . . . . . . . . . 41

4. Nataša Kljajić, Jonel Subić, Zorica Sredojević

PROFITABILITY OF RASPBERRY PRODUCTION

ON HOLDINGS IN THE TERRITORY OF ARILJE. . . . . . . . . . . 57

5. Aleksandar Maksimović, Zoran Grgić, Ferhat Ćejvanović

MULTI-ATTRIBUTE ANALYSIS OF ORCHARD ACCORDING

TO THE INTEGRATED PRODUCTION CONCEPT . . . . . . . . . . 69

6. Ozrislava Milinković, Branislav Jakić, Slobodan Vuksanović,

Dragana Macura, Milica Šelmić

MULTI- CRITERIA DECISION BASED APPROACH

TO SELECTING THE TYPE OF INDUSTRIAL HALLS

USED IN FOOD INDUSTRY $\ldots \ldots \ldots \ldots$. . . . . . . . . . 81

7. Gordana Nikić, Ljubiša Stamatović, Azra Sućeska

EMOTIONAL COMPETENCIES AND PERSONALITY

TRAITS OF MANAGERS IN MODERN AGROBUSINESS. . . . . . . .97

8. Vladimir Obradović, Nemanja Karapavlović

FINANCIAL REPORTING OF COMPREHENSIVE INCOME

IN THE FOOD AND BEVERAGE SECTOR

IN THE REPUBLIC OF SERBIA . . . . . . . . . . . . . . 113 
9. Aleksandar Ostojić, Nebojša Savić, Željko Vaško

CONSUMER ATTITUDES

ON BUYING FISH IN BANJA LUKA . . . . . . . . . . . . . . . 129

10. Radivoj Prodanović, Boris Kuzman, David Jovović, Lazar Ozegović

MARKET AND TRADE OF ORGANIC FRUITS IN SERBIA $\ldots . . .141$

11. Predrag Vukadinović, Aleksandar Damnjanović, Ljiljana Dimitrijević

ANALYSIS OF THE SALES AND INCOMES BETWEEN

DIFFERENT CATEGORIES OF AGRICULTURAL PRODUCTS . . . 157

12. Jugoslav Aničić, Svetlana Vukotić, Goran Maksimović

THE POSSIBILITIES AND LIMITATIONS

OF ENTREPRENEURSHIP DEVELOPMENT

IN AGRICULTURE IN SERBIA . . . . . . . . . . . . . . 171

13. Željko Bjelajac, Marijana Dukić - Mijatović, Joko Dragojlović

FOOD SAFETY AS ONE OF THE MAIN SAFETY $P$

REOCCUPATIONS OF A MODERN MAN . . . . . . . . . . . . . 191

14. Milan Bradić, Ljiljana Kosar, Lukrecija Djeri, Svetlana Vukosav, Vuk Garača

ECO-LABELLING OF ACCOMMODATION FACILITIES

AND ITS PERCEPTION BY RURAL TOURISTS:

CASE STUDY OF VOJVODINA . . . . . . . . . . . . . . 205

15. Vaso Jegdić, Iva Škrbić, Srđan Milošević

MODELS OF ENTREPRENURSHIP DEVELOPMENT

IN RURAL TOURISM DESTINATIONS IN VOJVODINA . . . . . . . 221

16. Duško Kuzović

MUSEUM OF VERNACULAR ARCHITECTURE OF WESTERN SERBIA

- Representative curtilages of the area surrounding middle

course of the river Drina and Podgorina . . . . . . . . . . . 239

17. Branko Mihailović, Zoran Simonović, Nikola Ćurčić

AGRICULTURAL RESOURCES AND DEVELOPMENT

PRIORITIES OF THE MUNICIPALITY OF STARA PAZOVA. . . . . 259

18. Radmilo Nikolić, Aleksandra Fedajev, Vidoje Stefanović, Silvana Ilić

THE AGRICULTURE SECTOR IN WESTERN BALKANS

- SOME CHARACTERISTICS OF DEVELOPMENT. . . . . . . . . . 275

19. Vladimir Njegomir, Rajko Tepavac, Nenad Ivanišević

ALTERNATIVE SOURCES OF FINANCING

ENTREPRENEURIAL UNDERTAKINGS IN AGRICULTURE . . . 295

Economics of Agriculture, Year 64, No. 1 (1-404) 2017, Belgrade 
20. Daniela Nuševa, Kristina Mijić, Dejan Jakšić

THE PERFORMANCES OF COFFEE PROCESSORS

AND COFFEE MARKET IN THE REPUBLIC OF SERBIA . . . . . . 307

21. Svetlana Roljević Nikolić, Predrag Vuković, Biljana Grujić

MEASURES TO SUPPORT THE DEVELOPMENT OF ORGANIC

FARMING IN THE EU AND SERBIA . . . . . . . . . . . . 323

22. ŽeljkoVojinović, Vera Zelenović, DragoCvijanović

PROGRAM OF STATE SUPPORT

TO AGRICULTURAL CREDITING. . . . . . . . . . . . . . . . 339

23. Nikola Vuksanović, Dragan Tešanović, Bojana Kalenjuk,

Milijanko Portić, Marija Knežević

SOCIO-DEMOGRAPHIC CHARACTERISTICS

AS DETERMINANTS OF DIFFERENCES

IN PERCEPTION OF LOCAL GASTRONOMY . . . . . . . . . . . . 359 